\title{
An Open Repository of Earthquake-Triggered Ground-Failure Inventories
}

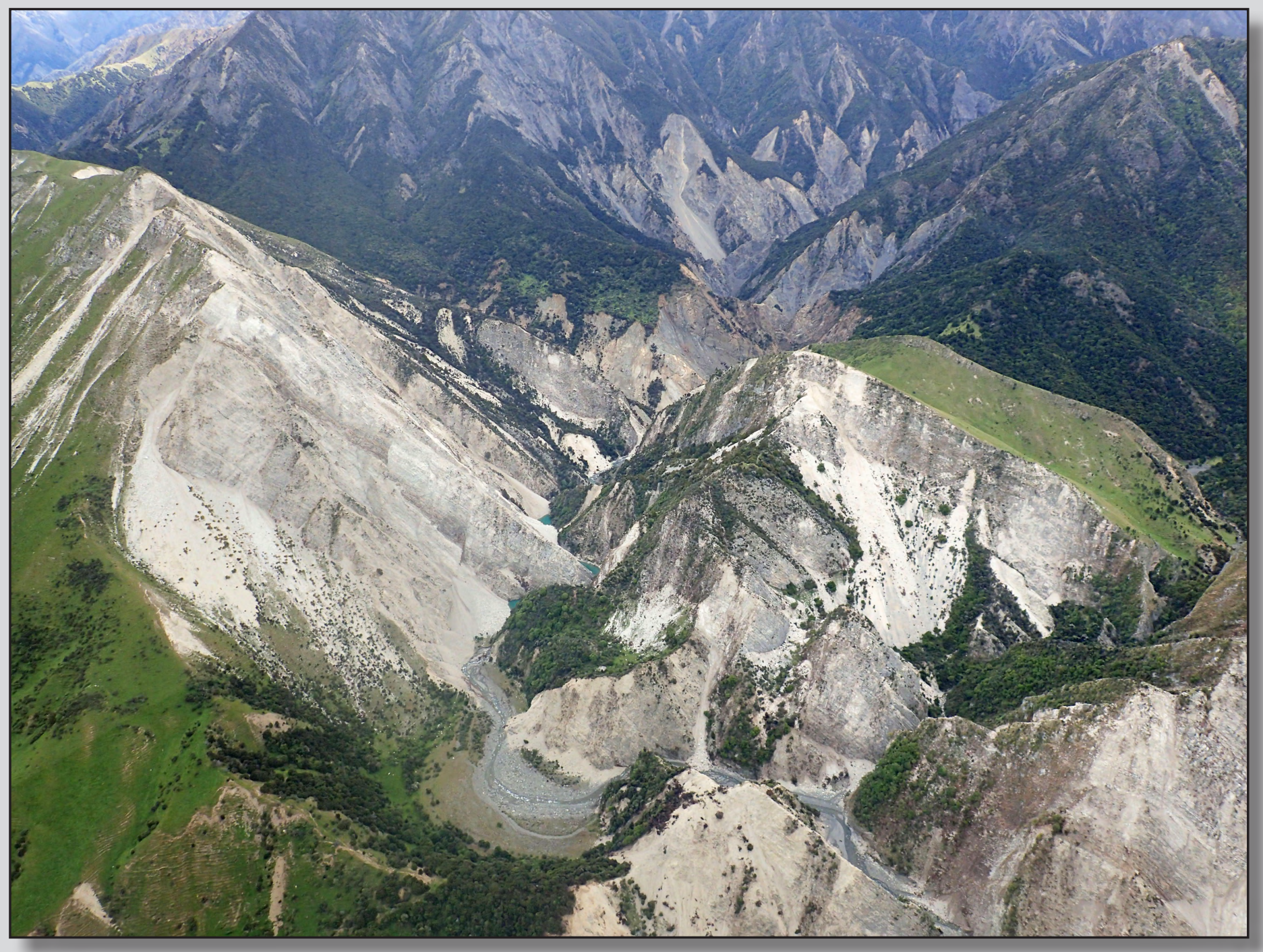

Data Series 1064

U.S. Department of the Interior

U.S. Geological Survey 
Cover: Shallow landslides triggered by the 2016 Kaikoura Earthquake in New Zealand. (Photo by Kate Allstadt) 


\section{An Open Repository of Earthquake- Triggered Ground-Failure Inventories}

By Robert G. Schmitt, Hakan Tanyas, M. Anna Nowicki Jessee, Jing Zhu, Katherine M. Biegel, Kate E. Allstadt, Randall W. Jibson, Eric M. Thompson, Cees J. van Westen, Hiroshi P. Sato, David J. Wald, Jonathan W. Godt,

Tolga Gorum, Chong Xu, Ellen M. Rathje, and Keith L. Knudsen

Data Series 1064

U.S. Department of the Interior

U.S. Geological Survey 


\title{
U.S. Department of the Interior \\ RYAN K. ZINKE, Secretary
}

\section{U.S. Geological Survey William H. Werkheiser, Acting Director}

\author{
U.S. Geological Survey, Reston, Virginia: 2017
}

For more information on the USGS - the Federal source for science about the Earth, its natural and living resources, natural hazards, and the environment-visit https://www.usgs.gov or call 1-888-ASK-USGS.

For an overview of USGS information products, including maps, imagery, and publications, visit https://store.usgs.gov.

Any use of trade, firm, or product names is for descriptive purposes only and does not imply endorsement by the U.S. Government.

Although this information product, for the most part, is in the public domain, it also may contain copyrighted materials as noted in the text. Permission to reproduce copyrighted items must be secured from the copyright owner.

Suggested citation:

Schmitt, R.G., Tanyas, Hakan, Nowicki Jessee, M.A., Zhu, Jing, Biegel, K.M., Allstadt, K.E., Jibson, R.W., Thompson, E.M., van Westen, C.J., Sato, H.P., Wald, D.J., Godt, J.W., Gorum, Tolga, Xu, Chong, Rathje, E.M., Knudsen, K.L., 2017, An open repository of earthquake-triggered ground-failure inventories: U.S. Geological Survey Data Series 1064, 17 p., https://doi.org/10.3133/ds1064.

ISSN 2327-638X (online) 


\section{Contents}

Abstract



Purpose

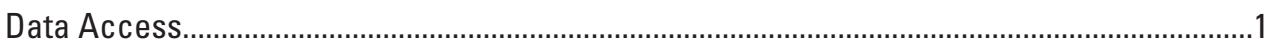

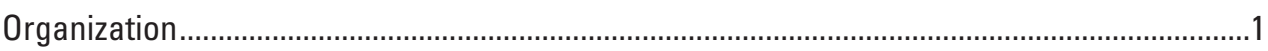

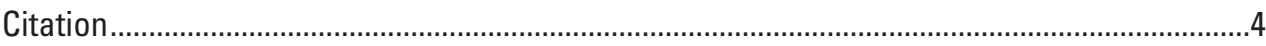

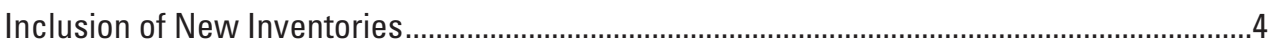

Original Data Sources and Processing Steps.............................................................................



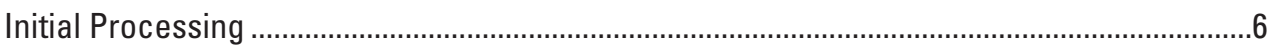



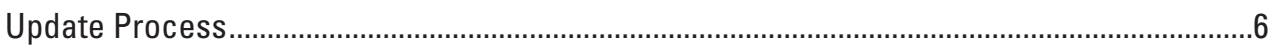

Field Names—Definitions, Data Types, and Descriptions .........................................................6

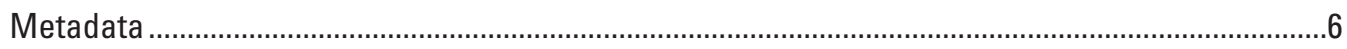

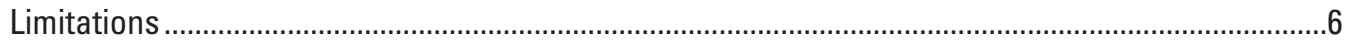

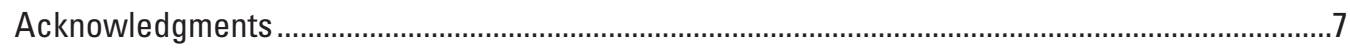

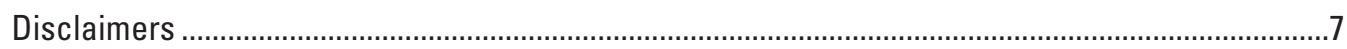

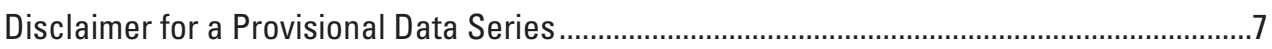

References Cited.................................................................................................................

Appendix 1. Earthquake-Triggered Landslide Inventory Author Method-Summary Form.............9

Appendix 2. Earthquake-Triggered Liquefaction Inventory Author Method-Summary Form......13

Appendix 3. Earthquake-Triggered Ground-Failure Inventory Author's Permission Form ...........17

\section{Figures}

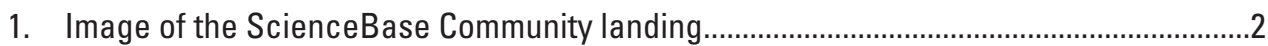

2. Images showing an example of the organization structure of the

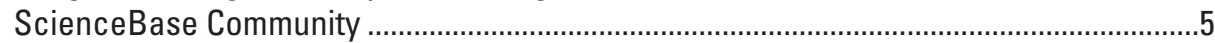

\section{Table}

1. Attribute field names, types, and descriptions ……......................................................... 



\title{
An Open Repository of Earthquake-Triggered Ground- Failure Inventories
}

\author{
By Robert G. Schmitt,' Hakan Tanyas, ${ }^{2}$ M. Anna Nowicki Jessee, ${ }^{3}$ Jing Zhu, ${ }^{4}$ Katherine M. Biegel, \\ Kate E. Allstadt, ${ }^{1}$ Randall W. Jibson, ${ }^{1}$ Eric M. Thompson, ${ }^{1}$ Cees J. van Westen, ${ }^{2}$ Hiroshi P. Sato, ${ }^{5}$ \\ David J. Wald, ${ }^{1}$ Jonathan W. Godt, ${ }^{1}$ Tolga Gorum, ${ }^{6}$ Chong Xu, ${ }^{7}$ Ellen M. Rathje, ${ }^{8}$ and Keith L. Knudsen ${ }^{1}$
}

\section{Abstract}

Earthquake-triggered ground failure, such as landsliding and liquefaction, can contribute significantly to losses, but our current ability to accurately include them in earthquake-hazard analyses is limited. The development of robust and widely applicable models requires access to numerous inventories of ground failures triggered by earthquakes that span a broad range of terrains, shaking characteristics, and climates. We present an openly accessible, centralized earthquake-triggered groundfailure inventory repository in the form of a ScienceBase Community to provide open access to these data with the goal of accelerating research progress. The ScienceBase Community hosts digital inventories created by both U.S. Geological Survey (USGS) and non-USGS authors. We present the original digital inventory files (when available) as well as an integrated database with uniform attributes. We also summarize the mapping methodology and level of completeness as reported by the original author(s) for each inventory. This document describes the steps taken to collect, process, and compile the inventories and the process for adding additional ground-failure inventories to the ScienceBase Community in the future.

\section{Overview}

To improve our ability to assess earthquake-triggered ground-failure hazard, the research community needs access to historical ground-failure inventory data. An inventory is a detailed map of individual ground failures that can be tied to a

\footnotetext{
${ }^{1}$ U.S. Geological Survey.

${ }^{2}$ University of Twente, The Netherlands.

${ }^{3}$ Indiana University, Bloomington, Indiana.

${ }^{4}$ Tufts University, Massachusetts. Now at AIR Worldwide, Boston.

${ }^{5}$ Nihon University, Japan.

${ }^{6}$ Istanbul University, Turkey.

${ }^{7}$ China Earthquake Administration, China.

${ }^{8}$ University of Texas, Austin, Texas.
}

single triggering event. These data can be used to improve our understanding of earthquake-triggered ground-failure hazard and allow us to produce models for probabilistic, scenario, and deterministic real-time hazard assessments.

\section{Purpose}

The purpose of this report is to outline the methods used to create a centralized repository for earthquake-triggered groundfailure inventories ("inventories"). The goal of this work is to help accelerate research progress by making it easier for the research community to access these datasets. When selecting data for a given research objective, researchers need to know the methodologies used to create the inventories and the limitations of the datasets. To address this need, we also report details from the original authors regarding mapping methodologies and levels of completeness.

\section{Data Access}

The data are hosted through a U.S. Geological Survey (USGS) ScienceBase Community. The ScienceBase Community, titled "An Open Repository of Earthquake-Triggered GroundFailure Inventories" is accessible at the following web address: https://doi.org/10.5066/F7H70DB4 (Schmitt and others, 2017). We structure the repository in a way that facilitates its inclusion in interactive web applications that could make the data even easier for the community to navigate.

\section{Organization}

Figure 1 shows the ScienceBase Comunity landing page for the data repository (https://doi.org/10.5066/F7H70DB4; Schmitt and others, 2017). A single combined geodatabase ("ground_failure_database_v\#.zip") and zip files of point and polygon shapefiles ("ground_failure_points_v\#.zip," "ground failure_polygons_v\#.zip") are hosted on the landing page for the ScienceBase Community, where v\# refers to the version of the release starting at v1. A Geodatabase is a native data structure for Esri ArcGIS, but it is proprietary so also included 
ScienceBase Catalog $\rightarrow$ An Open Repository of Earth..

\section{An Open Repository of Earthquake-triggered Ground-failure Inventories}

\section{Citation}

Schmitt, R., Tanyas, H., Jessee, M.A., Zhu, J., Biegel, K.M., Allstadt, K.E., Jibson, R.W., Thompson, E.M., van Westen, C.J., Sato, H.P., Wald, D.J., Godt, J.W., Gorum, T., Xu, C., Rathje, E.M., Knudsen, K.L., 2017, An Open Repository of Earthquake-triggered Ground Failure Inventories, U.S. Geological Survey data release collection, accessed DAY MONTH YEAR, at https://doi.org/10.5066/F7H70DB4.

\section{Summary}

Earthquake-triggered ground-failure, such as landsliding and liquefaction, can contribute significantly to losses, but our current ability to accurately include them in earthquake hazard analyses is limited. The development of robust and transportable models requires access to numerous inventories of ground failure triggered by earthquakes that span a broad range of terrains, shaking characteristics, and climates. We present an openly accessible, centralized earthquake-triggered ground-failure inventory repository in the form of a ScienceBase Community to provide open access to these data, and help accelerate progress. The Community hosts digital inventories created by both USGS and non-USGS authors. We present the original digital inventory files (when available) as well as an integrated database with uniform attributes. We also summarize the mapping methodology and level of completeness as reported by the original authors for each inventory.

\section{Contributing Inventories}

Contact gs-haz_groundfailure@usgs.gov for more information on how to contribute inventories to this effort.

\section{Child Items (2)}

$\boxplus$

Landslide Inventories

Liquefaction Inventories

\section{Contacts}

Contact : gs-haz_groundfailure@usgs.gov

\section{Attached Files}

Click on title to download individual files attached to this item or $\underline{\boldsymbol{t}}$ download all files listed below as a compressed file

\begin{tabular}{|c|c|c|c|}
\hline $\begin{array}{l}\text { ע landslide_methods_summary_v1.xlsx } \\
\text { "Summary of methods information provided by original authors" }\end{array}$ & $\begin{array}{l}\text { 2017-07-06 } \\
11: 13\end{array}$ & kallstadt@usgs.gov & $\begin{array}{l}49.73 \\
\mathrm{~KB}\end{array}$ \\
\hline $\begin{array}{l}\underline{\underline{\boldsymbol{t}}} \text { ground_failure_known_events_v1.xIsx } \\
\text { "Summary of published information on earthquakes that triggered } \\
\text { ground failure" }\end{array}$ & $\begin{array}{l}2017-07-06 \\
11: 14\end{array}$ & kallstadt@usgs.gov & $\begin{array}{l}70.98 \\
\mathrm{~KB}\end{array}$ \\
\hline $\begin{array}{l}\text { 上 ground_failure_database_v1.zip } \\
\text { "Geodatabase and metadata files" }\end{array}$ & $\begin{array}{l}2017-07-06 \\
14: 37\end{array}$ & rschmitt@usgs.gov & $\begin{array}{l}73.03 \\
\mathrm{MB}\end{array}$ \\
\hline $\begin{array}{l}\text { 上 ground_failure_points_v1.zip } \\
\text { "Point shapefile and metadata" }\end{array}$ & $\begin{array}{l}2017-07-06 \\
14: 38\end{array}$ & rschmitt@usgs.gov & $\begin{array}{l}3.43 \\
\mathrm{MB}\end{array}$ \\
\hline $\begin{array}{l}\text { ע ground_failure_polygons_v1.zip } \\
\text { "Polygon shapefile and metadata" }\end{array}$ & $\begin{array}{l}2017-07-06 \\
14: 41\end{array}$ & rschmitt@usgs.gov & $\begin{array}{l}187.96 \\
M B\end{array}$ \\
\hline
\end{tabular}

Figure 1. Image of the ScienceBase Community landing page located at https://doi.org/10.5066/F7H70DB4. 


\title{
Related External Resources
}

\author{
Type: ArcGIS Online Web Application \\ Ground-failure Database Web https://usgs.maps.arcgis.com/apps/webappviewer/index.html?id=de583ade9e9e \\ Application $\quad$ 4c4e89303ecf90359535
}

\section{Purpose}

\begin{abstract}
The goal of this work is to help accelerate research progress by making it easier for the research community to access these datasets. When selecting data for a given research objective, researchers need to know the methodologies used to create the inventories and the limitations of the datasets. To address this need, we also report details from the original authors regarding mapping methodologies and levels of completeness. We have chosen to structure the collection of inventories as a ScienceBase Community that can be updated regularly as new inventories are made available. The procedures and policies described in the accompany U.S. Geological Survey data series report, linked below, would be applied to new inventories prior to inclusion.
\end{abstract}

\section{Additional Information}

\section{Identifiers}

\begin{tabular}{|l|l|l|}
\hline Type & Scheme & Key \\
\hline DOI & https://www.sciencebase.gov/vocab/category/item/identifier & $10.5066 / F 7 H 70 D B 4$ \\
\hline
\end{tabular}

Figure 1. Image of the ScienceBase Community landing page located at https://doi.org/10.5066/F7H70DB4.—Continued

are shapefiles, an open format that can be used outside of ArcGIS but does not preserve symbology. Each file contains all of the publicly released ground-failure inventories that have the same attributes as the geodatabase (table 1). Additionally, the landing page hosts spreadsheets that summarize the responses of the corresponding author(s) for each inventory questionnaire regarding how the inventory was created (Appendixes 1 and 2). These are titled "landslide_methods_summary_v\#.xlsx" and "liquefaction_methods_summary_v\#.xlsx." As of the time of this writing, the liquefaction inventories are not yet prepared for release so the liquefaction methods summary file does not exist in version 1 and the known events summary is not yet as complete for liquefaction as it is for landslides. Also included is a summary of published information about earthquakes that are known to have triggered ground failure, including those that are not included in the inventory database. These data are included in a spreadsheet on the main ScienceBase Community landing page called "ground_failure_known_events_v\#.xlsx." Events include (1) earthquakes that are included in the inventory database, (2) earthquakes for which inventories have been published but are not currently included in the inventory database, (3) earthquakes with reported ground failures but no known inventories, such as those reported by Marano and others (2010), and (4) null events, which are defined as earthquakes that triggered little to no ground failure. A null event is distinct from an earthquake for which we have no information. Defining an event as null requires a report stating that no or minimal ground failure was observed despite a thorough survey of the affected area. Such events are rarely documented, but they are useful for modeling as they provide information about areas where ground failure did not take place despite earthquake shaking.

The inventories themselves can be found on the earthquake-event web pages, which are located under two folders on the main ScienceBase Community landing page: "Landslide Inventories" and "Liquefaction Inventories." Within each of these folders are links to earthquakeevent web pages, named by the date (year, month, day as YYYY-MM-DD), earthquake name, and magnitude (for example, 1986-10-10 San Salvador, El Salvador M 5.7) (fig. 2A). The earthquake names are derived from the USGS ShakeMap Atlas (García and others, 2012) event description field, for entries where a ShakeMap Atlas event exists. This is because these names correspond more closely to the commonly used name for each event than the geographical name automatically produced and used as the name on the USGS earthquake-event web page. If no ShakeMap Atlas event exists, the geographical name was used. Each ScienceBase earthquake-event web page (fig. $2 B$ ) contains a short summary statement about the earthquake, a link to the USGS earthquake-event web page, and one or more inventory web pages, which in ScienceBase fall under the "child items" subheading.

Each inventory web page is organized by the author name(s) and the publication year of the inventory (for example, Gorum and others, 2014). Author name(s) are the most commonly used discriminator between inventories for the same earthquake. Since many of the inventories from a given earthquake have similar titles, inventory web pages are labeled by author name(s) instead of the title for ease of navigation. Each individual inventory web page (fig. $2 C$ ) contains a short statement describing the inventory, a link to the original 
Table 1. Attribute field names, types, and descriptions.

[GIS, geographic information system; USGS, U.S. Geological Survey; UTC, Coordinated Universal Time]

\begin{tabular}{|c|c|c|}
\hline Field name & Field type & Description \\
\hline OBJECTID & Long integer & Identifier given to each feature when imported into the GIS \\
\hline event_name & Text & USGS official event name or ShakeMap Atlas name if available \\
\hline magnitude & Float & USGS event magnitude \\
\hline source_link & Text & Link to the inventory web page on ScienceBase \\
\hline epicentral_country & Text & Country where epicenter of triggering earthquake is located \\
\hline comments & Text & $\begin{array}{l}\text { Additional information from the original source related to the triggering event (for example, } \\
\text { part of an earthquake sequence) }\end{array}$ \\
\hline volume & Float & Volume of ground failure (cubic meters) if available from original dataset \\
\hline event_link & Text & Link to the respective USGS earthquake-event web page \\
\hline inventory_name & Text & Name of the inventory from which the data originated \\
\hline
\end{tabular}

data source (typically a journal paper), as well as a series of individual files that contain the original data with the original attributes. These files are also named by the author names and year of the original publication. Each inventory web page also contains a pdf of the original questionnaire filled out by the contributing author(s) regarding how the inventory was created (Appendixes 1 and 2).

\section{Citation}

Though many of the inventories were originally developed and analyzed as part of journal publications or reports, the inventories themselves - either in the form of analog maps or digital files - were rarely published with the article or report. Some inventories were never formally published at all. Inventories are also re-projected to a coordinate system consistent with other inventories in the repository. Therefore, in most cases, each inventory is considered a new data release, and each is granted a digital object identifier (doi) and a new citation. The author list and title from the original publication are used unless the original author(s) want to update the citation information or if the title needs to be modified to better describe the inventory dataset rather than the findings of the original research paper. In cases where the inventory has already been published on ScienceBase (which is the case for some USGS-affiliated inventories), the child item links to the existing ScienceBase entry.

An individual inventory web page should be cited like a chapter in a book, where the book is the ScienceBase Community landing page. An access date should also be included in the citation of the data release to take into account that new inventories may be added regularly. Suggested citations are presented on each ScienceBase earthquake-event web page. An example for the described citation format is as follows:

Harp, E.L., Tanaka, Kohei, Sarmiento, John, and Keefer, D.K., 2017, Landslides from the May 25-27, 1980, Mammoth Lakes, California, earthquake sequence,
https://doi.org/10.5066/F7M043X2, in Schmitt, R.G., Tanyas, Hakan, Nowicki, Jessee, M.A., Zhu, Jing, Biegel, K.M., Allstadt, K.E., Jibson, R.W., Thompson, E.M., van Westen, C.J., Sato, H.P., Wald, D.J., Godt, J.W., Gorum, Tolga., Xu, Chong, Rathje, E.M., and Knudsen, K.L., 2017, An open repository of earthquake-triggered ground-failure inventories: U.S. Geological Survey data release collection, accessed June 26, 2017, at https://doi.org/10.5066/F7H70DB4.

\section{Inclusion of New Inventories}

The collection of inventories is structured as a ScienceBase Community that can be updated regularly, following the procedures and policies described in this document, as new inventories are made available.

Researchers who wish to make their inventories available for inclusion in this effort should fill out the "author's method-summary form" and "author's permission form" (Appendixes 1-3). These forms are provided on the ScienceBase Community landing page. The forms and the data, preferably in shapefile format, should be sent to gs-haz_groundfailure@usgs.gov. Submission is not a guarantee of inclusion. Inventories that are associated with peerreviewed reports or scientific papers are preferred.

\section{Original Data Sources and Processing Steps}

\section{Data Sources}

The ground-failure inventories included in this repository were generated independently by numerous USGS and non-USGS authors. The authors of inventories who agree to include their inventories as part of this effort share the digital files and fill out a questionnaire describing how the inventory 


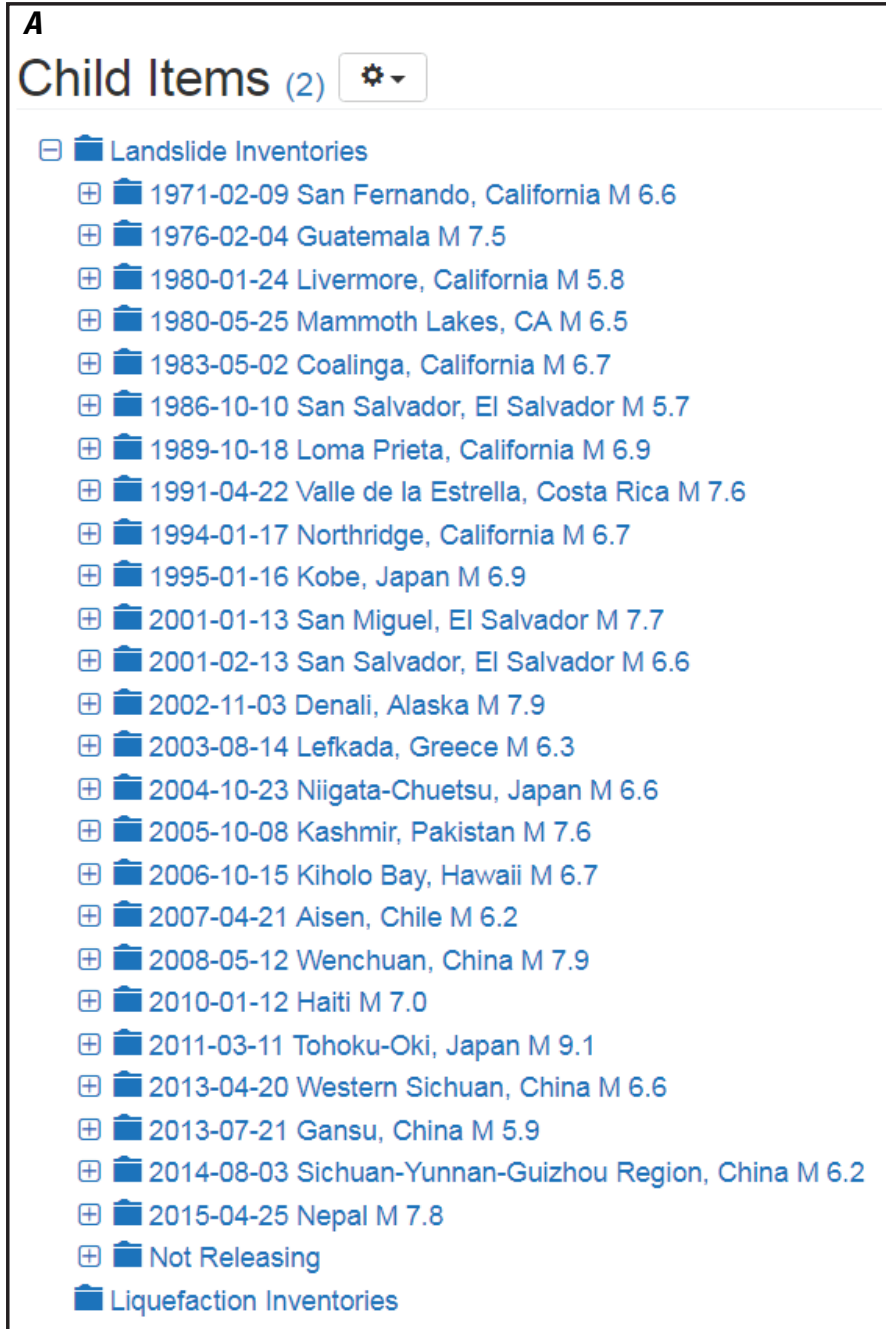

B

ScienceBase Catalog $\rightarrow$ An Open Repository of Earth $\ldots \rightarrow$ Landslide Inventories $\rightarrow$ 2010-01-12 Haiti M 7.0

\section{0-01-12 Haiti M 7.0}

\section{Summary}

This folder contains landslide inventories of the Mw 7.0 Haiti earthquake, which occurred on 2010-01-12 at 21:53:10 UTC. The hypocenter was located at $18.443^{\circ} \mathrm{N} 72.571^{\circ} \mathrm{W}$ at a depth of $13.0 \mathrm{~km}$. For further information see the link ts the full USGS event page for this earthquake under "Related External Resources" below.

With the exception of the data from USGS sources, the inventory data and associated metadata were not acquired b the U.S. Geological Survey (USGS) and thus have not been reviewed for accuracy and completeness by the USGS. They are presented as part of this data series for convenience of the user only, as part of an effort to make published ground-failure inventories more accessible from a single aggregated site. No warranty, expressed or implied, is made regarding the display or utility of the data on any other system or for general or scientific purposes, nor shall the act 0 distribution constitute any such warranty.

\section{Child Items (2) क्.}

圆 Gorum and others (2013)

国 Harp and others (2016)

Related External Resources

Type: Web Link

USGS Earthquake Event Page

http://earthquake. usgs.gov/earthquakes/eventpage/usp000h60h
C

Harp and others (2016)

Map of landslides triggered by the January 12, 2010, Haiti earthquake

Dates

Publication Date : 2017

Start Date : 2010-01-12

End Date : 2016

\section{Citation}

Harp, E.L., Jibson, R.W., Schmilt, R.G., 2017, Map of landslides triggered by the January 12, 2010, Haiti earthquake, htips://doi. org/10.5066/F7C827SR, in Schmitt, R. Tanyss, H., Nowicki Jessee, M.A., Zhu, J., Biegel, K.M., Allstadt. K.E., Jitson, R.W., Thompson, E.M., van Westen, C.J., Sato, H.P., Wald, D.J., Godt, J.W., Gorum. T., Xu, C., Rathje, EM. Knudsen, KL 2017, An Open Repository of Earthquake-triggered Ground Failure Inventories, U.S. Geologica Survey data release collection, accessed June 26.2017, at htps://doi.org/10.5056/F7-H70DB4.

\section{Summary}

This inventory was originally created by Harp and others (2016) describing the landslides triggered by the $M 7.0 \mathrm{Hait}$ earthquake that occurred on 12 January 2010 at 21:53:10 UTC. Care should be taken when comparing with other inventories bexause dirterent authors use direrent mapping techniques. This inventory also could be assoclated with other earthquakes such as aftershocks or triggered events. Please check the author methods summary and the original data source for more information on these details and to confirm the viability of this inventory for your specife

Contacts

Point of Contact : GHSC Data Steward

Originator: Harp, E.L, Jibson, R.W., Schmitt, R.

Metadata Contact: GHSC Data Stewar

Publisher: None

Distributor: Sciencebase

\section{Attached Files}

Click on ittle to download individual files attached to this item or $\mathbf{t}$ download all flles listed below as a comoressed file. 1 Harp_and_others_2016_FGOC.xml Original FGDC Metacata \begin{tabular}{l|l|l|l} 
D 2017-06-27 16.56 kbiegel@usgs.gov $11.73 \mathrm{KE}$ &
\end{tabular}

Shapefile: \pm Harp_and_others_2016.zip

\begin{tabular}{|c|c|c|c|}
\hline 土 Harp_and_others_2016.cpg & b & $2017-02-03 \quad 10: 04$ & 5 Eytes \\
\hline I Harp_and_others_2016.dbf & $\mathbf{l}$ & $2017-02-03$ 10:04 & $2.81 \mathrm{MB}$ \\
\hline I Harp_and_others_2016.prj & i & $2017-02-0310: 04$ & 145 Byies \\
\hline 1 Harp_and_others_2016.sbn & & $2017 \cdot 02-03$ 10:04 & $226.39 \mathrm{~KB}$ \\
\hline 士 Harp_and_others_2016.sbx & & $2017-02-03$ 10:04 & $10.51 \mathrm{~KB}$ \\
\hline I Harp_and_others_2016.snp & & $2017-02-0310.05$ & $32.68 \mathrm{ME}$ \\
\hline I Hsrp_and_others_2016.shp.xml & lo & $2017-02-03$ 10:04 & $15.21 \mathrm{kB}$ \\
\hline 土 Harp_and_others_2016.shx & & $2017 \cdot 02-03$ 10:04 & $184.21 \mathrm{~KB}$ \\
\hline
\end{tabular}

\section{Related External Resources}

Type: Publication that references this resource

Harp, EL., Jibson. R.W., and Schmitt R.G. 2016, Map of landslides triggered by the January 12, htips://icoi. 2010. Hati earthquake: U.S. Geologis:al Survey Scientfic Invesigations Map 3353, 15 p, 1 sheet, rog/10.313: scale 1:150,000, do: $10.3133 / \operatorname{sim} 3353$

Figure 2. Images showing an example of the organization structure of the ScienceBase Community. $A$, Organization scheme for the earthquake-event web pages listed as child items on the main ScienceBase Community landing page. $B$, Example of an individual earthquake-event web page for which there are multiple inventories listed as child items. $C$, Example of an individual ground-failure inventory web page. 
was produced. Separate but similarly structured forms are used for landslides and liquefaction. Blank copies of these forms are included as Appendixes 1 and 2, respectively. Authors not affiliated with the USGS also fill out a form to grant permission to share their data through ScienceBase (Appendix 3). Some older inventories only exist as paper maps; these are digitized, georeferenced using the given coordinate system of each hardcopy map, and converted to shapefiles that can be used in a geographic information system (GIS).

\section{Initial Processing}

In most cases, inventories are received from their original authors as shapefiles with a defined georeferencing system, as noted by the authors in the corresponding "author's methodsummary form." The individual datasets are then loaded into a GIS, retaining their original attributes, and the dataset is exported to a new shapefile using the World Geodetic System 1984 (WGS84) coordinate system for consistency. Each inventory is then loaded onto its corresponding inventory web page on the ScienceBase Community.

\section{Database Creation and Processing}

A single-file geodatabase contains feature classes for ground-failure points, lines, and polygons. We also create a zip file of shapefiles containing the same information to make the database accessible outside proprietary platforms. Many opensource software packages can read and write shapefiles, but geodatabase files are accessible only in ArcGIS. Each dataset includes the same attribute schema (table 1). Each individual dataset is appended to the geodatabase, and attributes are populated based on the details of the inventory being added. The geodatabase is projected into WGS84 Web Mercator for an optimized web-viewing experience.

\section{Update Process}

The repository is structured as a ScienceBase Community to allow updates as more inventories become available. The update workflow will follow the same steps described in this document for the initial version of the database. All of the database files (geodatabase, shapefiles, excel spreadsheet summaries) are versioned to reflect new additions, and the most recent versions are available on the ScienceBase Community landing page.

\section{Field Names-Definitions, Data Types, and Descriptions}

Table 1 describes the attribute schema. Note that the description, comment, and volume fields are only populated if the relevant information is available from the original source. We did not derive any new values for these fields. The description field is reserved for information about the individual point or polygon, such as the type of landslide (for example, rock fall, debris flow). No classification information found in this field is altered. Since different groups use different classification schemes, these are not necessarily consistent between inventories and users should refer to the original publication for details. The comment field is reserved for information about the triggering event. For example, "This inventory includes landslides triggered by a sequence of earthquakes rather than a single main shock. Check original data source for details on the earthquake sequence."

\section{Metadata}

The information from the author-provided methodsummary forms is aggregated and transferred into an Excel spreadsheet containing all inventories, including the corresponding author(s). Using an automated python script, a separate preliminary metadata file in XML format is created for each inventory, sourcing the information from the Excel spreadsheet. Each automated metadata file includes authorprovided information as well as database-wide USGS metadata information such as USGS personnel contacts and disclaimers.

The preliminary metadata file is then used as the starting template to complete the geospatial section of the final metadata xml file. Each inventory is loaded into the USGS Metadata Wizard tool for ArcGIS. The tool uses the template created for each submission to populate the necessary fields in the XML file that pertained to that submission. The Metadata Wizard then adds geospatial attributes associated with the corresponding inventory to the XML file. The geospatial attributes include the datum and projection, attribute definitions, and geoprocessing steps. The newly created XML files with the author(s) and geospatial information are then loaded onto the correct ScienceBase inventory web page.

\section{Limitations}

This database does not include all of the earthquakeinduced ground-failure inventories that exist. Inventories are not included for which we do not have permission from the original authors to redistribute data and there may be datasets of which we are not aware, such as in the international literature or in non-English-language journals or gray-literature reports.

Many different researchers with varying methods, objectives, and priorities generated the inventories included in this database. Therefore, the inventories vary in quality, completeness, and representation. The geographic and thematic accuracy of the mapped features differs significantly between inventories. The level of detail, such as whether source areas and runouts are mapped separately for landslides or whether the ground failure is represented as a point or as a polygon, also varies significantly. The author's method-summary forms, 
which were completed by the original authors of the inventories and were not independently verified, are provided in the database. In addition, users should verify the spatial accuracy of the landslide locations. Except for the conversion of the coordinate system, the original inventories were not modified. Therefore, the spatial accuracy of the shared data depends on the quality of the original data. In the inventories that were digitized, the accuracy of the ground-failure localities differs based on the scale and accuracy of the original map.

The inventories are linked to the largest triggering earthquake both on ScienceBase and in their metadata and attributes. A statement is placed on the ScienceBase inventory web page and in the metadata of inventories for which the original report noted that the mapped landslides were triggered by a sequence of earthquakes rather than a single main shock. However, other inventories may also include landslides triggered by other earthquakes or other causes, so the user should refer to the original report of the corresponding inventory for more information.

Users interested in utilizing the landslide inventories in this database should be aware of these limitations and work with the most suitable datasets for their purpose with knowledge of the accompanying uncertainties.

\section{Acknowledgments}

For the sharing of their data up to the time of this report, the authors are very grateful to following researchers: Kristin Marano, Daisuke Higaki, Fumitoshi Imaizumi, Gen Li, George Papathanassiou, Hiroshi Yagi, Jianqiang Zhang, Joseph Wartman, Kaushal Raj Gnyawali, Mario Reyes, Muhammad Basharat, Odin Marc, Pascal Lacroix, Salvatore Martino, Sergio Sepúlveda, Taro Uchida, and Tsuyoshi Wakatsuki.

\section{Disclaimers}

With the exception of the data from USGS sources, the inventory data and associated metadata were not acquired by the USGS, are published as they were submitted, and thus have not been reviewed for accuracy and completeness by the USGS. They are presented as part of this data series for convenience of the user only, as part of an effort to make published ground-failure inventories more accessible by aggregating them onto a single website. No warranty, expressed or implied, is made regarding the display or utility of the data on any other system or for general or scientific purposes, nor shall the act of distribution constitute any such warranty.
All USGS data, metadata, and related materials are considered to satisfy the quality standards relative to the purpose for which the data were collected. Although these data and associated metadata have been reviewed for accuracy and completeness and approved for release by the USGS, no warranty expressed or implied is made regarding the display or utility of the data for other purposes, nor on all computer systems, nor shall the act of distribution constitute any such warranty.

\section{Disclaimer for a Provisional Data Series}

Data secured from this USGS data series are provisional and subject to revision. The data are released on the condition that neither the USGS nor the U.S. Government may be held liable for any damages resulting from their authorized or unauthorized use.

\section{References Cited}

García, Daniel, Mah, R.T., Johnson, K.L., Hearne, M.G., Marano, K.D., Lin, K.W., Wald, D.J., Worden, C.B., and So, Emily, 2012, ShakeMap Atlas 2.0-An improved suite of recent historical earthquake ShakeMaps for global hazard analyses and loss model calibration, in World Conference on Earthquake Engineering, 15th, Lisbon, Spain, 24-28 Sept 2012: Lisbon, Spain, International Association for Earthquake Engineering, $10 \mathrm{p}$.

Gorum, Tolga, Korup, Oliver, van Westen, C.J., van der Meijde, Mark, Xu, Chong, and van der Meer, F.D., 2014, Why so few? Landslides triggered by the 2002 Denali earthquake, Alaska: Quaternary Science Reviews, v. 95, p. 80-94, accessed September 10, 2015, at https://doi.org/10.1016/j.quascirev.2014.04.032.

Marano, K.D., Wald, D.J., and Allen, T.I., 2010, Global earthquake casualties due to secondary effects - A quantitative analysis for improving rapid loss analyses: Natural Hazards, v. 52 no. 2, p. 319-328, accessed June 28, 2017 , at https://doi.org/10.1007/s11069-009-9372-5.

Schmitt, R.G.; Tanyas, Hakan; Nowicki Jessee, M.A.; Zhu, Jing; Biegel, K.M.; Allstadt, K.E.; Jibson, R.W.; Thompson, E.M.; van Westen, C.J.; Sato, H.P.; Wald, D.J.; Godt, J.W.; Gorum, Tolga; Xu, Chong; Rathje, E.M.; and Knudsen, K.L., 2017, An open repository of earthquake-triggered ground-failure inventories: U.S. Geological Survey data release collection, accessed September 11, 2017, at https://doi.org/10.5066/F7H70DB4. 



\section{Appendix 1. Earthquake-Triggered Landslide Inventory Author Method- Summary Form}

Complete a separate metadata form for each inventory. Please fill in all items, even though they might be in associated publications, in order to provide a complete metadatabase. Return form and necessary attachments to gs-haz_groundfailure@usgs.gov.

1. Earthquake-induced-landslide inventory name

Name of inventory (include earthquake name):

Date of triggering earthquake (Coordinated Universal Time):

2. Projection system of the inventory

Projection system:

Remarks:

3. Method(s) used for generating the inventory

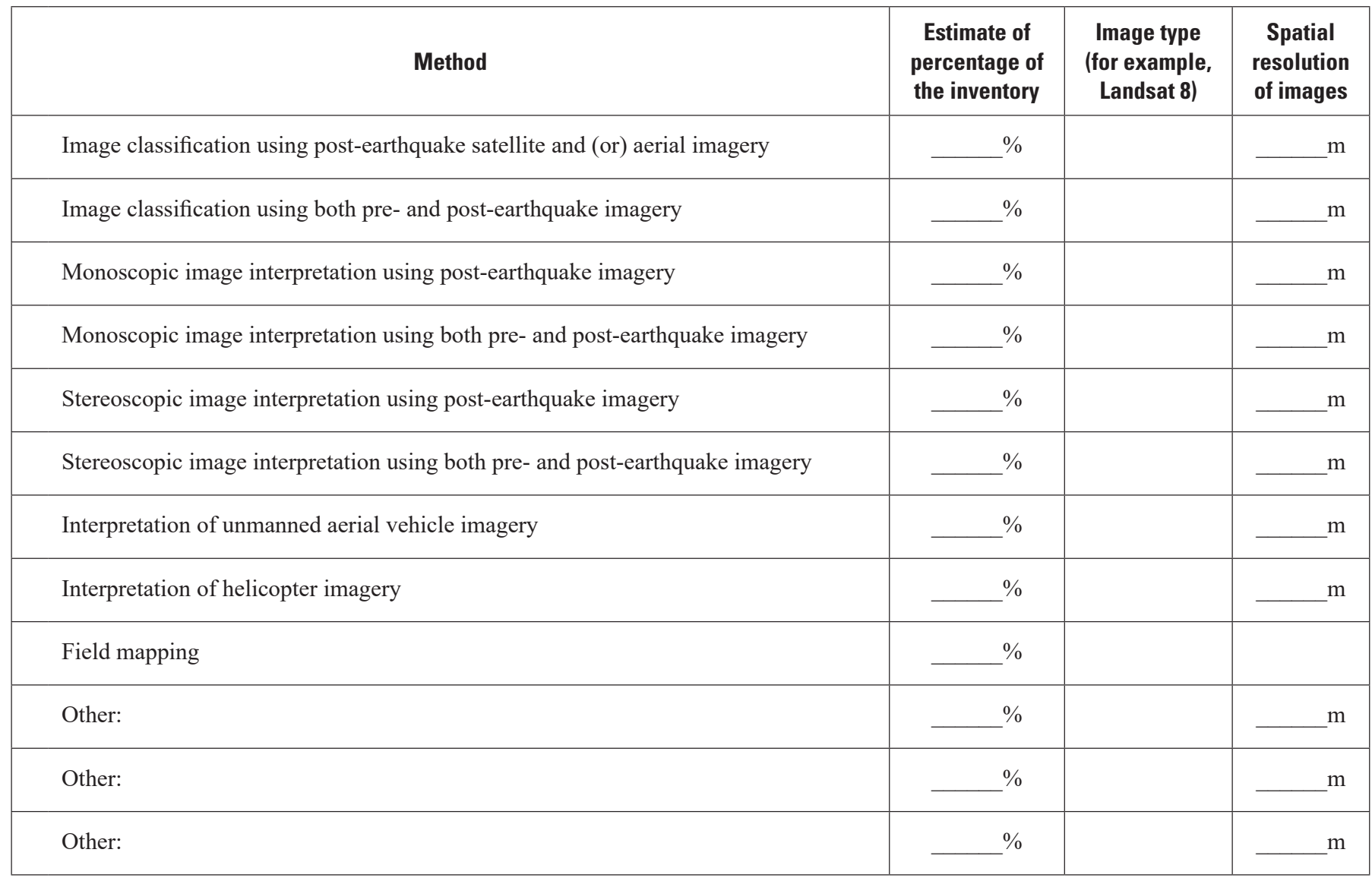

Remarks: 


\section{An Open Repository of Earthquake-Triggered Ground-Failure Inventories}

4. Completeness of the inventory

\begin{tabular}{|c|c|}
\hline Was a minimum size threshold used for mapping landslides? & $\begin{array}{l}\square \text { Yes: } \_\mathrm{m}^{2} \\
\square \text { No }\end{array}$ \\
\hline Estimated percentage of landslides from the triggering earthquake that were mapped & $\%$ \\
\hline $\begin{array}{l}\text { Is the boundary of the mapped area indicated? } \\
\text { If yes, send this as an attachment, if possible. }\end{array}$ & $\begin{array}{l}\square \text { Yes } \\
\square \text { No }\end{array}$ \\
\hline $\begin{array}{l}\text { Were pre-earthquake landslides removed from the inventory? } \\
\text { If yes, explain how. }\end{array}$ & $\begin{array}{l}\square \text { Yes } \\
\square \text { No }\end{array}$ \\
\hline Percentage of landslides mapped as points & $\%$ \\
\hline Percentage of landslides mapped as polygons & $\%$ \\
\hline Were source and deposition parts of the landslides differentiated? & $\begin{array}{l}\square \text { Yes, for } \_ \text {_ } \% \text { of landslides } \\
\square \text { No }\end{array}$ \\
\hline Were contiguous landslides mapped separately or as a single landslide? & $\begin{array}{l}\square \text { Separately, for } \quad \% \\
\text { of the landslides } \\
\square \text { As a single feature, for } \\
\text { of the landslide }\end{array}$ \\
\hline $\begin{array}{l}\text { Were the landslide types classified? } \\
\text { If yes, based on which classification method? }\end{array}$ & $\begin{array}{l}\square \text { Yes } \\
\square \text { No }\end{array}$ \\
\hline \multicolumn{2}{|l|}{ What other landslide attributes were included? } \\
\hline Attribute: & How was this attribute obtained? \\
\hline Attribute: & How was this attribute obtained? \\
\hline Attribute: & How was this attribute obtained? \\
\hline
\end{tabular}

Remarks: 
5. Landslide inventory mapping effort

\begin{tabular}{|l|l|}
\hline Were problematic areas field checked after creating the inventory? & $\begin{array}{l}\square \text { Yes, _ } \\
\text { No }\end{array}$ \\
\hline How of field was checked
\end{tabular}

Remarks:

6. Please list any additonal information collected as part of this inventory (such as samples, lidar, borings)

7. Referencing for the study

\begin{tabular}{|l|l|}
\hline Was the inventory published? & $\square$ Yes \\
If yes, please indicate the full reference for the study. & $\square$ No \\
& \\
\hline $\begin{array}{l}\text { Are there any other related studies that were not converted into an inventory map? } \\
\text { If yes, please send as an attachment or provide a link. }\end{array}$ & $\square$ Yes \\
\end{tabular}

Remarks:

8. Additional remarks or comments 



\section{Appendix 2. Earthquake-Triggered Liquefaction Inventory Author Method- Summary Form}

Complete a separate metadata form for each inventory. Please fill in all items, even though they might be in associated publications, in order to provide a complete metadatabase. Return form and any attachments to gs-haz_groundfailure@usgs.gov.

1. Earthquake-induced-liquefaction inventory name

Name of inventory (include earthquake name):

Date of triggering earthquake (Coordinated Universal Time):

2. Projection system of the inventory

Projection system:

Remarks:

3. Method(s) used for generating the inventory

\begin{tabular}{|c|c|c|c|}
\hline Method & $\begin{array}{l}\text { Estimate of } \\
\text { percentage of } \\
\text { the inventory }\end{array}$ & $\begin{array}{c}\text { Image type } \\
\text { (for example, } \\
\text { Landsat 8) }\end{array}$ & $\begin{array}{c}\text { Spatial } \\
\text { resolution } \\
\text { of images }\end{array}$ \\
\hline Image classification using both pre- and post-earthquake imagery & - $\%$ & & m \\
\hline Image interpretation using both pre- and post-earthquake imagery & $\%$ & & m \\
\hline Interpretation of unmanned aerial vehicle imagery & $\%$ & & $\mathrm{~m}$ \\
\hline Other: & $\%$ & & m \\
\hline Other: & $\%$ & & $\mathrm{~m}$ \\
\hline
\end{tabular}

Remarks: 


\section{An Open Repository of Earthquake-Triggered Ground-Failure Inventories}

4. Completeness of the inventory

\begin{tabular}{|c|c|}
\hline Estimated percentage of liquefaction from the triggering earthquake that was mapped & $\%$ \\
\hline $\begin{array}{l}\text { Is the boundary of the mapped area indicated? } \\
\text { If yes, send this as an attachment, if possible. }\end{array}$ & $\begin{array}{l}\square \text { Yes } \\
\square \text { No }\end{array}$ \\
\hline $\begin{array}{l}\text { Are the land routes of the mapping indicated? } \\
\text { If yes, send this as an attachment, if possible. }\end{array}$ & $\begin{array}{l}\square \text { Yes } \\
\square \text { No }\end{array}$ \\
\hline Percentage of liquefaction mapped as points & $\%$ \\
\hline Percentage of liquefaction mapped as polygons & $\%$ \\
\hline $\begin{array}{l}\text { Were the effects of the liquefaction differentiated (for example, sand boil, lateral spreading, } \\
\text { ground cracking)? }\end{array}$ & $\begin{array}{l}\square \text { Yes, for } \_\% \text { of liquefaction } \\
\square \text { No }\end{array}$ \\
\hline Was vertical settlement due to liquefaction measured? & $\begin{array}{l}\square \text { Yes, for } \_\% \text { of liquefaction } \\
\square \text { No }\end{array}$ \\
\hline \multicolumn{2}{|l|}{ What other liquefaction attributes were included? } \\
\hline Attribute: & How was this attribute obtained? \\
\hline
\end{tabular}

Remarks: 
5. Liquefaction inventory mapping effort

\begin{tabular}{|l|l|}
\hline If image classification or interpretation was used, were the results field validated? & \begin{tabular}{l}
$\square$ Yes, $\begin{array}{c}\text { \% of mapped features were } \\
\text { checked } \\
\text { No }\end{array}$ \\
\hline If image interpretation was used, were the results crosschecked by others? \\
$\square$ Yes \\
$\square$ No
\end{tabular} \\
\hline How long after the earthquake was the inventory completed? & months \\
\hline
\end{tabular}

Remarks:

6. Please list any additional information collected as part of this inventory (such as samples, lidar, borings)

7. Referencing for the study

Was the inventory published?

If yes, please indicate the full reference for the study.

Yes

$\square$ No

Are there any other related studies that were not converted into an inventory map?

Yes

If yes, please send as an attachment or provide a link.

No

Remarks:

8. Additional remarks or comments: 



\section{Appendix 3. Earthquake-Triggered Ground-Failure Inventory Author's Permission Form}

Name:

Organization:

Address:

E-mail:

Date:

$\square$ I am interested in becoming a member of an international working group on earthquake-induced ground failure.

$\square$ I am willing to share the following earthquake-induced inventories on a web-based platform:

\begin{tabular}{|l|l|l|}
\hline Location & Country & Date of triggering earthquake (UTC) \\
\hline & & \\
\hline & & \\
\hline & & \\
\hline
\end{tabular}


Publishing support provided by:

Denver Publishing Service Center, Denver, Colorado

For more information concerning this publication, contact:

Center Director, USGS Geologic Hazards Science Center

Box 25046, Mail Stop 966

Denver, CO 80225

(303) 273-8579

Or visit the Geologic Hazards Science Center website at: https://www.usgs.gov/centers/geohazards

This publication is available online at: https://doi.org/10.3133/ds1064 

